\title{
QUALITY CHARACTERISTICS OF THE MIXTURES OF SOME WARM SEASON PERENNIAL GRASSES WITH ALFALFA (Medicago sativa L.) UNDER IRRIGATED CONDITIONS OF CUKUROVA
}

\author{
Selahattin CINAR ${ }^{1^{*}}$, Rustu HATIPOGLU ${ }^{2}$ \\ ${ }^{I}$ Gaziosmanpasa University, Faculty of Agriculture, Department of Field Crops, Tokat, TURKEY \\ ${ }^{2}$ Cukurova University, Faculty of Agriculture, Department of Field Crops, Adana, TURKEY \\ *Corresponding author: scinar01@ hotmail.com
}

Received: 10.09.2014

\begin{abstract}
This research was conducted to determine forage quality characteristics of duo (alfalfa + one grass) and trio ( alfalfa + two grasses) mixtures of some warm season perennial grass species such as dallis grass (Paspalum dilatatum Poir.), Rhodes grass (Chloris gayana L.) and Bermuda grass (Cynodon dactylon (L.) Pers.) with alfalfa as well as their pure sowings under irrigated conditions of Cukurova during the years of 2009-2011. In the study, crude protein contents, crude protein yields, acid detergent fiber contents (ADF), neutral detergent fiber contents (NDF) and relative feed values (RFV) of the mixtures and pure sowings were determined. The experimental design was completely randomized block design with three replications. The results of the study showed that there were significant differences among mixtures and pure sowings in the forage quality characteristics. The highest crude protein yield $\left(2.32 \mathrm{t} \mathrm{ha}^{-1}\right)$ was obtained from the mixture of dallis grass + alfalfa. The highest crude protein ratio $(20.6 \%)$ and RFV (164.8) was obtained from the pure alfalfa. The highest ADF (40.2 \%) and NDF (70.9 \%) was obtained from the pure dallis grass. The result of the study indicated that duo mixture of alfalfa with dallis grass may be used to establish artificial pastures under irrigated conditions of Cukurova or of similar ecologies owing to its high forage quality and high crude protein yield.
\end{abstract}

Key words: Warm season perennial grasses, alfalfa, mixture, quality

\section{INTRODUCTION}

Grass-legume mixtures are preferred over pure-grass forage stands throughout the world because they often increase the total yields of herbage and protein and offer balanced nutrition (Albayrak and Ekiz, 2005). Some other advantages of mixtures include the control of erosion, weed control and prolonged stand longevity (Casler, 1988). Alfalfa is one of the most commonly used legumes for both hay and pasture in Turkey because of its high yield, high nutritional quality, ability to fix nitrogen and vigorous fall regrowth (Acikgoz, 2001).

Grass-legume mixtures tend to provide a superior nutrient balance and produce higher forage yields. The benefit of including legumes in mixture with grasses has long been recognized. Introducing legumes in pastures and hay fields improves forage quality and lowers the cost of production (Brown and Munsell, 1943). Legumes provide proteins that grasses lack and increase dry matter yield by fixing atmospheric nitrogen and converting it into a soluble inorganic form that can be absorbed into plant tissues.
In contrast to the above mentioned benefits of the grass-legume mixtures, they are more difficult to manage than monoculture pastures because of competition among the mixture components for light, water, and nutrients (Charles and Lehmann, 1989; Serin et al., 1998; Berdahl et al., 2001; Albayrak and Ekiz, 2005).

The advantages of cool season legumes in cool season pastures and hay lands have been well documented, but there is little information on mixing legumes with warm season grasses. Some researchers reported that warmseason forage crops could be succesfully grown in mixtures with legumes (Aganoglu 1985; Blanchet et al., 1995; Larbi et al., 1995; Gettle et al., 1996; Tessema and Baars 2006).

Mediterranean region of the Turkey experiences long periods of drought, especially in mid-summer. High temperatures and low precipitation are detrimental to production of cool season forages. Lack of productivity of cool season pastures during the summer months often results in overgrazing. Perennial warm season grasses produce their yields in midsummer, which could provide forage production during that period (Jung et al., 1978). 
Rhodes grass is one of the main sub-tropical grasses and is widely grown in Africa, Australia, Japan, South America as well as in the Middle East under irrigation for both forage and soil conservation purposes (Tansi, 2009). Rhodes grass is a morphologically variable out-crossing species, which is native to east, central and southern Africa where it occurs in open grasslands.

Dallis grass is a summer-active perennial grass native to the humid sub-tropics of southern Brazil, Argentina and Uruguay ( Jones, 1985). It is now widespread in many areas of the world, and is capable of very high production under suitable conditions.

Bermuda grass is native to southern Africa and southeast Asia. It has been widely used in tropical and warm temperate regions as a pasture grass and is one of the major turf grasses in the world. Bermuda grass is widely sown in the south-eastern United States, where its hybrid cultivars with improved productivity and forage quality have been developed (Skerman and Riveros, 1990).

This paper was prepaired from a part of data obtained from the research conducted to determine the forage yields and qualities of duo (one grass + alfalfa) and trio (two grass + alfalfa) mixtures of some perennial warm season grass species such as dallis grass (Paspalum dilatatum Poir.), Rhodes grass (Chloris gayana L.), Bermuda grass (Cynodon dactylon (L.) Pers.) with alfalfa (Medicago sativa L.) as well as their pure growings under irrigated conditions of Mediterranean. A paper from data related to the yields and some other characteristics of the mentioned mixtures as well as pure growings had been published ( Cinar and Hatipoglu, 2014).

\section{MATERIALS AND METHODS}

\section{Plot establishment}

The research was carried out during 2009-2011 growing seasons in Adana province $\left(36^{\circ} 51^{\prime} \mathrm{N}, 35^{\circ} 20^{\prime} \mathrm{E}\right.$, elevation $12 \mathrm{~m})$, located in the Mediterranean region of Turkey. The experimental area has typically natural Mediterranean climate with hot and dry summer and heavy precipitation during winter. According to the average of long years, the coolest month is January with a monthly mean temperature of $9.9^{\circ} \mathrm{C}$ and the hottest month is August with $28.8^{\circ} \mathrm{C}$. The total precipitation was lower in $2010(500.6 \mathrm{~mm})$ and $2011(462.3 \mathrm{~mm})$, and higher in $2009(671.6 \mathrm{~mm})$ when compared with the long-term precipitation mean $(647.1 \mathrm{~mm})$. The means of the temperature and relative humidity during the experimental period were close to the long-term means (Anonymous, 2012a). The research area has a flat land; its soil texture is classified as silty clay with slightly alkaline, which contained medium organic matter, poor phosphorus $(\mathrm{P})$, zinc ( $\mathrm{Zn}$ ) and calcium (Ca) contents (Anonymous, 2007).

Dallis grass (Paspalum dilatatum Poir.), Rhodes grass (Chloris gayana L.), Bermuda grass (Cynodon dactylon (L.) Pers.) and alfalfa (Medicago sativa L.) as welll as their duo (one grass + alfalfa) and trio (two grass + alfalfa) mixtures were used as experimental material.
The experiment was conducted according to the randomized complete block design with three replications. There were 10 treatment plots in each block. Each plot consisted of 6 rows each $5 \mathrm{~m}$ in length. The row spacing was $25 \mathrm{~cm}$. The seeding rates for dallis grass, Rhodes grass, Bermuda grass and alfalfa were $11 \mathrm{~kg} \mathrm{ha}^{-1}, 4 \mathrm{~kg} \mathrm{ha}^{-}$ $1,10 \mathrm{~kg} \mathrm{ha}^{-1}$ and $10 \mathrm{~kg} \mathrm{ha}^{-1}$ respectively. Seed mixtures consisted of $30 \%$ alfalfa and $70 \%$ grasses. Seed ratio of each grass species in trio mixtures was $35 \%$. The seeds of alfalfa and grass species were sown in the same rows. Sowing was done by hand on April $28^{\text {th }} 2009$. Plots were fertilized with $100 \mathrm{~kg} \mathrm{ha}^{-1} \mathrm{~N}$ and $100 \mathrm{~kg} \mathrm{ha}^{-1} \mathrm{P}$ at sowing (Avci, 2000). The plots were irrigated once after each harvest.

\section{Methods}

The harvest time was based on the $10 \%$ flowering stage of alfalfa (Serin et al., 1998). The plots were harvested at $5 \mathrm{~cm}$ cutting height. The plots were harvested 4, 6 and 5 times during the growing seasons of 2009, 2010 and 2011, respectively. The forage samples for the quality analyses were taken from the 3 randomly located quadrates each having $0.5 \mathrm{~m}^{2}$ area in each plot.

All samples were dried at $70{ }^{\circ} \mathrm{C}$ for $48 \mathrm{~h}$ and weighed. The samples from the mixture plots were hand-separated to the mixture components before the drying. Dry matter content was determined from ground samples dried at 105 ${ }^{\circ} \mathrm{C}$ for $24 \mathrm{~h}$.

Contents of crude protein, acid detergent fiber (ADF) and neutral detergent fiber (NDF) of samples were determined using Infrared Reflectance Spectroscopy (NIRS) (Hoy et al., 2002; Aydin et al., 2010). NIRS was calibrated using software program coded IC-0904 FE hay and fresh forage.

Crude protein yield (CPY), digestible dry matter yield (DDMY), dry matter intake (DMI), digestible dry matter (DDM) and relative feed value (RFV) were estimated according to the following equations adapted from Sheaffer et al. (1995): (DMY)

$$
\begin{aligned}
& \mathrm{DMI}=120 /(\mathrm{NDF} \%) \text { dry matter basis } \\
& \mathrm{DDM}=88.9-(0.779 \times \mathrm{ADF} \% \text { dry matter basis }) \\
& \mathrm{RFV}=(\mathrm{DDM} \% \times \mathrm{DMI}) / 1.29
\end{aligned}
$$

\section{Experimental design and statistical analyses}

The experimental design was completely randomized block design with 3 replications. Data were analyzed by using MSTATC software program (V.1.2, Michigan State University, USA). The differences between means were separated by Duncan multiple range test $(\mathrm{P} \leq 0.05)$, however means of year were compared according to least significant difference (LSD) test $(\mathrm{P} \leq 0.05)$ ( Steel and Torrie, 1960). 


\section{RESULTS AND DISCUSSION}

\section{Crude Protein Ratio and Crude Protein Yield}

The results of the variance analysis showed that the crude protein ratio was influenced by pure sowings and mixtures as well as years. Year $\mathrm{x}$ treatment (pure sowings and mixtures) interaction was also statistically significant. Averaged crude protein ratios in the second and third years were significantly higher than that in the first year (Table 1). The alfalfa sown in April, normally sown in November under Mediterranean conditions, produced lower hay yield than that sown in November in the first year. Therefore contribution of the alfalfa on the yield of the mixtures in the first year was significantly lower than those in the second and third years. Lower alfalfa ratio in the hay yields of mixtures in the first year resulted in the lower averaged crude protein ratio than those in the second and third years.

Table 1. Crude protein ratios (\%) of dry matters from pure sowings and alfalfa-grass mixtures

\begin{tabular}{|c|c|c|c|c|}
\hline \multirow{2}{*}{ Pure Sown and mixtures } & \multicolumn{3}{|c|}{ Years } & \multirow{2}{*}{ Average } \\
\hline & 2009 & 2010 & 2011 & \\
\hline Alfalfa (A) & $20.2 \mathrm{a}^{*}$ & $21.0 \mathrm{a}$ & $20.5 \mathrm{a}$ & $20.6 \mathrm{a}$ \\
\hline Dallis grass (DG) & 11.4 ef. & $8.4 \mathrm{e}$ & $9.9 \mathrm{~d}$ & $9.9 \mathrm{f}$ \\
\hline Bermuda grass (BG) & $13.9 \mathrm{~cd}$ & $9.3 \mathrm{e}$ & $10.8 \mathrm{~d}$ & $11.4 \mathrm{e}$ \\
\hline Rhodes grass (RG) & $10.0 \mathrm{f}$ & $9.6 \mathrm{e}$ & $10.5 \mathrm{~d}$ & $10.0 \mathrm{f}$ \\
\hline $\mathrm{A}+\mathrm{DG}$ & $14.2 \mathrm{~b}$ & $16.6 \mathrm{~cd}$ & $17.4 \mathrm{~b}$ & $16.0 \mathrm{c}$ \\
\hline $\mathrm{A}+\mathrm{BG}$ & $16.5 \mathrm{~b}$ & $18.5 \mathrm{~b}$ & $18.2 \mathrm{~b}$ & $17.7 \mathrm{~b}$ \\
\hline$A+R G$ & $11.9 \mathrm{c}-\mathrm{f}$ & $15.6 \mathrm{~d}$ & $14.4 \mathrm{c}$ & $14.0 \mathrm{~d}$ \\
\hline $\mathrm{A}+\mathrm{DG}+\mathrm{RG}$ & $11.6 \mathrm{~d}-\mathrm{f}$ & $16.3 \mathrm{~cd}$ & $13.2 \mathrm{c}$ & $13.7 \mathrm{~d}$ \\
\hline $\mathrm{A}+\mathrm{BG}+\mathrm{DG}$ & $13.2 \mathrm{c}-\mathrm{e}$ & $17.3 \mathrm{bc}$ & $17.1 \mathrm{~b}$ & $15.9 \mathrm{c}$ \\
\hline $\mathrm{A}+\mathrm{BG}+\mathrm{RG}$ & $11.9 \mathrm{c}-\mathrm{f}$ & $16.1 \mathrm{~cd}$ & $13.0 \mathrm{c}$ & $13.7 \mathrm{~d}$ \\
\hline Average & $13.5 \mathrm{~b}+$ & $14.9 \mathrm{a}$ & $14.5 \mathrm{a}$ & 14.3 \\
\hline
\end{tabular}

+ ) Values within the row with different letters are significantly different from each other according to the LSD Test at $\mathrm{P} \leq 0.05$

In the first year, crude protein content of alfalfa dry matter was statistically significant higher than those of the other pure sowings and all of the mixtures (Table 1). Rhodes grass gave the dry matter with statistically significant lower crude protein ratio than pure growings of alfalfa and Bermuda grass as well as than the mixtures of alfalfa+dallis grass and alfalfa+Bermuda grass.

In the second year, alfalfa produced the dry matter with statistically significant higher crude protein content than all of the other pure sowings and mixtures. All of the pure sowings of the grasses gave the dry matter with statistically significant lower crude protein content than the pure sowing of alfalfa and all of the mixtures.

In the third year, the highest crude protein content $(20.5 \%)$ was obtained from pure sown alfalfa as in the first and second years. All of the pure sowings of the grasses gave the dry matter with statistically significant lower crude protein content than the pure sowing of alfalfa and all of the mixtures as in the second year.

According to the averaged values over three years, the highest crude protein ratio was obtained from pure sown alfalfa. Pure sowings of dallis grass and Rhodes grass produced the dry matter with statistically significant lower crude protein content than the other pure sowings and mixtures.

Previous studies have shown that alfalfa contains significantly more protein than grasses and that grass+legume mixtures contain more crude protein than the pure sowing grasses (Spandl and Hesterman, 1997; Avci, 2000; Albayrak and Ekiz, 2005).

Nutrient value of a forage relatively depends on the botanical composition and harvesting time. The results indicated that $\mathrm{CP}$ contents of dry matter of the mixtures were generally lower than $16-18 \%$ which requires supplementary feeding to obtain high performance from milk cows (Baytekin and Gul, 2009).

The crude protein yield (CPY) significantly varied depending on the years. The averaged crude protein yield in first year was significantly lower than those in the second and third years (Table 2). The variation in the crude protein yield of the pure sowings and mixtures depending on the years was due to the variation in dry matter yield and crude protein ratio. 
Table 2. Crude protein yields $\left(\mathrm{t} \mathrm{ha}^{-1}\right)$ of pure sowings and alfalfa-grass mixtures

\begin{tabular}{|c|c|c|c|c|}
\hline Pure Sown and mixtures & 2009 & $\begin{array}{l}\text { Years } \\
2010\end{array}$ & 2011 & Average \\
\hline Alfalfa (A) & 1.40 & $2.71 \mathrm{a}^{*}$ & $2.31 \mathrm{bc}$ & $2.14 \mathrm{a}$ \\
\hline Dallis grass (DG) & 1.24 & $0.59 \mathrm{~b}$ & $0.60 \mathrm{e}$ & $0.81 \mathrm{c}$ \\
\hline Bermuda grass (BG) & 1.33 & $0.68 \mathrm{~b}$ & $0.60 \mathrm{e}$ & $0.87 \mathrm{c}$ \\
\hline Rhodes grass (RG) & 1.46 & $0.93 \mathrm{~b}$ & $1.18 \mathrm{~d}$ & $1.19 \mathrm{c}$ \\
\hline $\mathrm{A}+\mathrm{DG}$ & 1.39 & $2.68 \mathrm{a}$ & $2.90 \mathrm{a}$ & $2.32 \mathrm{a}$ \\
\hline $\mathrm{A}+\mathrm{BG}$ & 1.62 & $2.50 \mathrm{a}$ & $2.61 \mathrm{ab}$ & $2.24 \mathrm{a}$ \\
\hline$A+R G$ & 1.72 & $2.34 \mathrm{a}$ & $2.07 \mathrm{bc}$ & $2.04 \mathrm{ab}$ \\
\hline $\mathrm{A}+\mathrm{DG}+\mathrm{RG}$ & 1.55 & $2.32 \mathrm{a}$ & $2.08 \mathrm{bc}$ & $1.99 \mathrm{ab}$ \\
\hline $\mathrm{A}+\mathrm{BG}+\mathrm{DG}$ & 1.08 & $2.12 \mathrm{a}$ & $1.78 \mathrm{c}$ & $1.66 \mathrm{~b}$ \\
\hline $\mathrm{A}+\mathrm{BG}+\mathrm{RG}$ & 1.51 & $2.69 \mathrm{a}$ & $2.16 \mathrm{bc}$ & $2.12 \mathrm{a}$ \\
\hline Average & $1.43 \mathrm{~b}+$ & $1.96 \mathrm{a}$ & $1.83 \mathrm{a}$ & 1.74 \\
\hline
\end{tabular}

*Values within a column with different letters are significantly different from each other according to the Duncan Test at $\mathrm{P} \leq 0.05$

+ ) Values within the row with different letters are significantly different from each other according to the LSD Test at $\mathrm{P} \leq 0.05$

In the first year of the experiment, the CPY was not statistically significant changed among the pure sown plots and mixtures. In the second year, pure growing alfalfa and its mixtures with grasses gave statistically significant higher CPY than all of the other pure sown grasses. In the third year, the mixture of alfalfa + dallis grass gave statistically significant higher crude protein yield than the pure sowings and the other mixtures with the exception of the alfalfa + Bermuda grass mixture.

According to the averaged values over three years, the highest crude protein yield was obtained from the mixture of alfalfa + dallis grass. The crude protein yield of this mixture was not statistically significant different from that of pure sown alfalfa and all of the mixtures with the exception of the trio mixture of alfalfa+Bermuda grass+ dallis grass.

\section{$A D F$ and NDF ratios}

The results of the variance analysis showed that ADF and NDF contents of the dry matter were statistically significant influenced by pure sowing and mixtures. as well as the years. Interaction of the years and treatments was also statistically significant. The averaged ADF content over the pure sowings and mixtures in the first year was significantly higher than those in the second and third years (Table 3). In the first year, contribution of the warm season grasses on the hay yield of the mixtures was higher than those in the second and third years. The grasses contain generally higher ADF than alfalfa (Linn and Martin, 1999). Therefore averaged ADF content of the dry matter in the first year was significantly higher than those in the second and third years.

Table 3. ADF ratios of dry matters from pure sowings and alfalfa-grass mixtures (\%)

\begin{tabular}{|c|c|c|c|c|}
\hline Pure Sown and mixtures & 2009 & $\begin{array}{l}\text { Years } \\
2010\end{array}$ & 2011 & Average \\
\hline Alfalfa (A) & $29.7 \mathrm{~d}^{*}$ & $24.2 \mathrm{e}$ & $26.2 \mathrm{~d}$ & $26.7 \mathrm{e}$ \\
\hline Dallis grass (DG) & $43.4 \mathrm{a}$ & $39.6 \mathrm{a}$ & $37.7 \mathrm{a}$ & $40.2 \mathrm{a}$ \\
\hline Bermuda grass (BG) & $35.7 \mathrm{c}$ & $32.6 \mathrm{~b}$ & $30.9 \mathrm{c}$ & $33.1 \mathrm{c}$ \\
\hline Rhodes grass (RG) & $39.8 \mathrm{~b}$ & $34.3 \mathrm{~b}$ & $34.6 \mathrm{~b}$ & $36.2 \mathrm{~b}$ \\
\hline $\mathrm{A}+\mathrm{DG}$ & $38.8 \mathrm{~b}$ & $30.3 \mathrm{c}$ & $30.6 \mathrm{c}$ & $33.2 \mathrm{c}$ \\
\hline $\mathrm{A}+\mathrm{BG}$ & $34.0 \mathrm{c}$ & $26.3 \mathrm{~d}$ & $26.7 \mathrm{~d}$ & $29.0 \mathrm{~d}$ \\
\hline $\mathrm{A}+\mathrm{RG}$ & $39.4 \mathrm{~b}$ & $29.0 \mathrm{c}$ & $29.9 \mathrm{c}$ & $32.7 \mathrm{c}$ \\
\hline $\mathrm{A}+\mathrm{DG}+\mathrm{RG}$ & $40.0 \mathrm{~b}$ & $29.4 \mathrm{c}$ & $32.1 \mathrm{bc}$ & $33.8 \mathrm{c}$ \\
\hline $\mathrm{A}+\mathrm{BG}+\mathrm{DG}$ & $36.2 \mathrm{c}$ & $28.4 \mathrm{~cd}$ & $26.9 \mathrm{~d}$ & $30.5 \mathrm{~d}$ \\
\hline $\mathrm{A}+\mathrm{BG}+\mathrm{RG}$ & $40.1 \mathrm{~b}$ & $28.1 \mathrm{~cd}$ & $31.3 \mathrm{c}$ & $33.1 \mathrm{c}$ \\
\hline Average & $37.7 \mathrm{a}+$ & $30.2 \mathrm{~b}$ & $30.7 \mathrm{~b}$ & 32.9 \\
\hline
\end{tabular}

*Values within a column with different letters are significantly different from each other according to the Duncan Test at $\mathrm{P} \leq 0.05$

+ ) Values within the row with different letters are significantly different from each other according to the LSD Test at $\mathrm{P} \leq 0.05$

In all the experimental years and according to the averaged values over the three years, alfalfa gave the dry matter with statistically significant lower ADF content than the other pure sowings and all of the mixtures. In contrast to this, dallis grass produced the dry matter with statistically significant higher ADF content than the other pure sowings and all of the mixtures in all of the experimental years. The reasons of the higher ADF content of dallis grass could be development stage of the plant at the harvest (Anonymous, 2012b) as well as the lower leaf- stem ratio (Pinkerton and Cross, 1992).

The averaged NDF ratio of dry matter in the first year was statistically significant higher than those in the second and third year (Table 4). As mentioned above, higher 
grass ratio in the hay yield of the mixtures in the first year than those in the second and third years resulted in the higher NDF content. As for ADF content, in all of the experimental years, alfalfa produced the dry matter with the statistically significant lower NDF content than the other pure sowings and all of the mixtures. On the other hand, pure sowings of the grasses gave the dry matter with higher NDF content.

Table 4. NDF ratios of dray matters from pure sowing and alfalfa grass-mixtures (\%)

\begin{tabular}{|c|c|c|c|c|}
\hline \multirow{2}{*}{ Pure Sown and mixtures } & \multicolumn{3}{|c|}{ Years } & \multirow{2}{*}{ Average } \\
\hline & 2009 & 2010 & 2011 & \\
\hline Alfalfa (A) & $39.4 \mathrm{~d}^{*}$ & $37.0 \mathrm{f}$ & $39.2 \mathrm{~d}$ & $38.5 \mathrm{f}$ \\
\hline Dallis grass (DG) & $75.4 \mathrm{a}$ & $69.7 \mathrm{a}$ & $67.5 \mathrm{a}$ & $70.9 \mathrm{a}$ \\
\hline Bermuda grass (BG) & $75.8 \mathrm{a}$ & $64.5 \mathrm{~b}$ & $64.4 \mathrm{a}$ & $68.2 \mathrm{~b}$ \\
\hline Rhodes grass (RG) & $73.9 \mathrm{a}$ & $66.6 \mathrm{~b}$ & $66.5 \mathrm{a}$ & $69.1 \mathrm{ab}$ \\
\hline $\mathrm{A}+\mathrm{DG}$ & $67.1 \mathrm{bc}$ & $49.4 \mathrm{~cd}$ & $47.7 \mathrm{c}$ & $54.7 \mathrm{~d}$ \\
\hline $\mathrm{A}+\mathrm{BG}$ & $61.9 \mathrm{c}$ & $43.8 \mathrm{e}$ & $44.5 \mathrm{c}$ & $50.1 \mathrm{e}$ \\
\hline$A+R G$ & $72.3 \mathrm{ab}$ & $50.7 \mathrm{c}$ & $54.2 \mathrm{~b}$ & $59.1 \mathrm{c}$ \\
\hline $\mathrm{A}+\mathrm{DG}+\mathrm{RG}$ & $71.0 \mathrm{ab}$ & $49.4 \mathrm{~cd}$ & $57.1 \mathrm{~b}$ & $59.1 \mathrm{c}$ \\
\hline $\mathrm{A}+\mathrm{BG}+\mathrm{DG}$ & $70.0 \mathrm{ab}$ & $47.0 \mathrm{~d}$ & $47.8 \mathrm{c}$ & $54.9 \mathrm{~d}$ \\
\hline $\mathrm{A}+\mathrm{BG}+\mathrm{RG}$ & $72.1 \mathrm{ab}$ & $49.5 \mathrm{~cd}$ & $53.7 \mathrm{~b}$ & $58.4 \mathrm{c}$ \\
\hline Average & $67.9 \mathrm{a}+$ & $52.8 \mathrm{c}$ & $54.3 \mathrm{~b}$ & 58.3 \\
\hline
\end{tabular}

The ADF concentration refers to the cell wall portion of the forage. The portion consist of cellulose and lignin. The ADF value is important because it describes the ability of an animal to digest the forage. As the ADF increases, the digestibility of the forage usually decreases. The NDF value refers to the total cell wall, composed of the ADF fraction plus hemicellulose. NDF value is important in ration formulation because it reflect the amount of forage that the animal can consume. As the NDF percentages increase, the dry matter intake will generally decrease (Joachim and Jung, 1997; Albayrak et al., 2011). Horner et al. (1985) determined ADF content of alfalfa as $35.3-41.1 \%$ while Cassida et al. (2000) reported it as $29.7-33.5 \%$, ADF content of the mixture of Rhodes grass + white sweet clover was reported by Corletto et al. (2009) as $37.0 \%$. Horner et al. (1985) determined NDF content of alfalfa as $46.0 \%$ while Cassida et al. (2000) reported it as $37.8-42.0 \%$. Jeranyama and Garcia (2004) reported a NDF value of 54 $\%$ for the mixture of alfalfa + grasses of mixtures. Tessema and Baars (2006) determined NDF values for Rhodes grass and for the mixture of alfalfa + Rhodes grass as $55.7 \%$ and $46.9 \%$, respectively. Lemus (2009) reported a NDF value of 67.2 - $67.6 \%$ for dallis grass. Some of our findings are consistent with those above mentioned, some of them are incompatible. Differences between the findings may be due to differences in climatically conditions, under which researches were conducted, and management techniques applied in the researches (Linn and Martin, 1999; Belyea et al. 1999; Bani et al. 2007).

\section{Relative Feed Value (RFV)}

The results of the variance analysis showed that RFV was statistically significant influenced by pure sowings and mixtures as well as years. Year x mixture interaction was also statistically significant. The averaged RFV over the pure sowings and mixtures significantly changed depending on the years. The averaged RFV in the second year was statistically significant higher than those in first and third years while the averaged RFV in the third year was higher than that in the first year (Table 5). The higher alfalfa contribution to the hay yield of the mixtures in the second and third years as compared to the first year resulted in higher RFV in those years. RFV is inversely proportional to the $\mathrm{ADF}$ and NDF. Therefore higher averaged RFV's were obtained in the second and third years in which ratios of NDF and ADF were lower than those in the first year. 
Table 5. RFV's of pure sowings and alfalfa- grass mixtures (\%)

\begin{tabular}{lllll}
\hline Pure Sown and mixtures & $\mathbf{2 0 0 9}$ & Years & \multicolumn{2}{c}{ Average } \\
\hline Alfalfa (A) & $155.4 \mathrm{a} *$ & $176.4 \mathrm{a}$ & $162.8 \mathrm{a}$ & $164.8 \mathrm{a}$ \\
Dallis grass (DG) & $68.0 \mathrm{~d}$ & $77.4 \mathrm{f}$ & $82.1 \mathrm{f}$ & $75.8 \mathrm{f}$ \\
Bermuda grass (BG) & $75.0 \mathrm{~cd}$ & $91.6 \mathrm{e}$ & $93.7 \mathrm{ef}$ & $86.8 \mathrm{e}$ \\
Rhodes grass (RG) & $72.8 \mathrm{~cd}$ & $86.6 \mathrm{e}$ & $86.7 \mathrm{f}$ & $82.1 \mathrm{e}$ \\
A+DG & $94.3 \mathrm{~b}$ & $145.2 \mathrm{~b}$ & $142.4 \mathrm{~b}$ & $127.3 \mathrm{~b}$ \\
A+BG & $81.8 \mathrm{c}$ & $123.1 \mathrm{~cd}$ & $127.0 \mathrm{c}$ & $110.6 \mathrm{c}$ \\
A+RG & $75.1 \mathrm{~cd}$ & $121.7 \mathrm{~d}$ & $112.8 \mathrm{~d}$ & $103.2 \mathrm{~d}$ \\
A+DG+RG & $80.7 \mathrm{c}$ & $132.4 \mathrm{c}$ & $132.5 \mathrm{bc}$ & $115.2 \mathrm{c}$ \\
A+BG+DG & $74.5 \mathrm{~cd}$ & $126.6 \mathrm{~cd}$ & $112.5 \mathrm{~d}$ & $104.5 \mathrm{~d}$ \\
A+BG+RG & $75.8 \mathrm{~cd}$ & $124.5 \mathrm{~cd}$ & $104.3 \mathrm{de}$ & $101.5 \mathrm{~d}$ \\
Average & $85.3 \mathrm{c}+$ & $120.6 \mathrm{a}$ & $115.7 \mathrm{~b}$ & 107.2 \\
\hline
\end{tabular}

*Values within a column with different letters are significantly different from each other according to the Duncan Test at $\mathrm{P} \leq 0.05$

+ ) Values within the row with different letters are significantly different from each other according to the LSD Test at $\mathrm{P} \leq 0.05$

In all of the experimental years, pure sown alfalfa produced the dry matter with statistically significant higher RFV than the other pure sowings and all of the mixtures. According to the averaged values over the three years, the mixture of alfalfa + dallis grass produced the dry matter with statistically significant higher RFV than the other mixtures and all of the pure sown grasses.

Relative feed value (RFV) has been used for years to compare the quality of legume and legume/grass hays and silages. Having one index to price hay and predict animal performance has been very useful for livestock producers and hay farmers. Forages with an RFV value over 151, between 150-125, 124-103, 102-87, 86-75, and less than 75 are categorized as prime, premium, good, fair, poor and rejected respectively (Kiraz, 2011, Uzun, 2010; Albayrak, 2011). According to these index values, pure sowing alfalfa is classified as prime while mixture of alfalfa + dallis grass is classified as premium.

\section{CONCLUSIONS}

From the results of the study, it was concluded that the duo mixture of alfalfa and dallis grass could be recommended as the summer pasture mixture for irrigated conditions in the Mediterranean region due to its moderate crude protein ratio, high crude protein yield, moderate ADF and NDF content sa well as its premium RFV. It was reported that this mixture was also in the group with higher dry matter yield and the highest LER value as compaired with the pure sowings and the mixtures mentioned in this study (Cinar and Hatipoglu, 2014).

\section{LITERATURE CITED}

Acikgoz, E. 2001. Forage Crops. Uludag University Faculty of Agriculture Publications, Bursa

Aganoglu, V. 1985. A Research on the possibility of growing Rhodes grass (Chloris gayana Kunth) and alfalfa (M. sativa L.) in mixture under Cukurova conditions. Msc thesis, Field Crops Department of Institute for Natural and Applied Sciences, Cukurova University, Adana.

Albayrak, S., H. Ekiz. 2005. An investigation on the establishment of artificial pasture under Ankara's ecological conditions. Turk J Agric For 29:69-74
Albayrak, S., M. Turk, O. Yuksel and M. Yilmaz. 2011. Forage yield and the quality of perennial legume-grass mixtures under rainfed conditions. Notulae Botanicae Horti Agrobotanici Cluj, 2011, 39(1):114-118.

Anonymous. 2007. Chemical Analysis Results, University of Cukurova Laboratory of Soil Science, Faculty of Agriculture, Adana, Turkey.

Anonymous.2012a. Meteorological data for Adana. http://www.wunderground.com (Accessed May, 10, 10,2013) (

Anonymous, 2012b. Paspalum dilatatum Poir. www.tropicalforages.info (Accessed January, 10,2012)

Avci, M. 2000. Determining suitable mixtures of cool season perennial grasses and legumes for establishment of short term pastures in Cukurova Region. Cukurova University, Institue of Natural and Applied Sciences, Department of Field Crops, 113 p. Adana

Aydin, N., Z.Mut, H.Mut, and İ.Ayan. 2010. Effect of autumn and spring sowing dates on hay yield and quality of oat (Avena sativa L.) genotypes. Journal of Animal and Veterinary Advances 9 (10):1539-1545

Bani, P., A.Minuti, A. O. Luraschi, M.Ligabue, and F.Ruozzi. 2007. Genetic and Enviromental Influences on In Vitro Digestibility of Alfalfa. Italia. Journal Animal Science., 6(1), 251-253.

Baytekin, H., ve İ.Gül. 2009. Forage Crops Harvest, Hay Yield and Storage, Forage, (Avcioğlu, R., Hatipoğlu, R. Karadağ, Y. Editor) Cilt III. TÜGEM, Emre p, İzmir, s: 121-141

Belyea, R., R.Restrepo, F.Martz, and M.Ellersieck. 1999. Effect of Year and Cutting on Equations for Estimating Net Energy of Alfalfa. Journal of Dairy Science, 82(9),1943-1949.

Berdahl, D. J., J.K.Karn, and J.R.Hendrickson. 2001. Dry Matter Yields of Cool-Season Grass Monocultures and GrassAlfalfa Binary Mixtures. Agronomy Journals, 93, 463-467.

Blanchet, K.M., J.R. George, R.M. Gettle, D.R. Buxton, and K.J. Moore. 1995. Establishment and persistence of legumes interseeded into switchgrass. Agron. J. 87: 935-941

Brown, B.A., R.I. Munsell. 1943. Grasses fertilized with nitrogen compared with legumes for hay and pasture. Agronomy Journal 35: 811-816

Cassida, K. A., T. S. Griffin, J.Rodriguez, S. C. Patching, O. B. Hesterman, and S. R.Rust. 2000. Protein Degradability and Forage Quality in Maturing Alfalfa, Red Clover and Birdsfoot Trefoil. Crop Science, 40, p: 209-215.

Casler, M.D. 1988. Performance of orchardgrass, smooth bromrgrass and ryegrass in binary mixtures with alfalfa. Agronomy Journal 80:509-514 
Charles, J.P., and J. Lehman. 1989. The İmportance Of Grass/Legume Mixtures İn Forage Production İn Switzerland. Fourages. 119:311-320

Cinar, S., and R. Hatipoglu. 2014. Forage yield and botanical composition of mixtures of some perennial warm season grasses with alfalfa (Medicago sativa L.) under Mediterranean conditions. Turkish Journal of Field Crops 19(1): 13-18

Corletto, A., E. Cazzato, P.Ventricelli, S.L.Cesentino, F.Gresta, G.Testa, M.Maiorana, F.Fornaro, D.De Giorgio. 2009. Performance of Perennial Tropical Grasses in Different Mediterannean Environments in Southern Italy. Tropical Grasslands Volume 43, (2009) p: 129-138. www.tropicalgrasslands.asn.au/

Gettle, R.M., J.R. George, K.M. Blanchet, D.R. Buxton, and K.J. Moore. 1996. Frost-seeding legumes into established switchgrass. Establishment, density, persistence, and sward composition. Agron. J. 88: 98-103

Horner, L.J., J.Bush, G.D.Adams, and C.M.Taliaferro. 1985. Comparative Nutritional Value of Eastern Gama grass and Alfalfa Hay for Dairy Cows, Journal of Dairy Science,( 68) $\mathrm{p}: 15-26$.

Hoy, M.D., K.J.Moore, J.R. George and E.E. Brummer. 2002. Alfalfa yield and quality as influenced by establishment method. Agron. J., 94:65-71

Jeranyama, P., and A.Garcia. 2004. Understanding Relative Feed Value (RFV) and Relative Forage Quality (RFQ). http://pubstorage.sdstate.edu/AgBio_Publications/articles/Ex Ex8149.pdf (Accessed May, 20, 2014)

Joachim, H., and G.Jung. 1997. Analysis of forage fiber and cell walls in ruminant nutrition. Journal of Nutrition 127:810-813

Jones, C,A. 1985. C4 Grassess and Cereals, John Willey\&Sons, Newyork,

Jung, G.A., C.F.Gross. R.E. Kocher, L.A.Burdette, and W.C.Sharp. 1978. Warm season range grasses extend beef cattle forage. Penn.Agric.Exp.Stn.Sci.Agric. 64:211-219

Kiraz, A.B. 2011. Determination of Relative Feed Value of Some Legume Hays Harvested at Flowering Stage, Asian Journal of Animal Veterinary Advances 6 (5): 525-530

Larbi, A., J.Lazier, J.Ochang, and A.Addie. 1995. Dry Matter Production of Thirteen Tropical Legumes İn Association with Rhodes Grass (Chloris gayana cv. Callide) on an Acid Soil in Etiopia. Tropical Grasslands Volume 29 p: 88-91.

Lemus, R. 2009. Seeding Warm Season Perennial Grasses. Forage News, Missisippi State University Extension Service, March-2009.

Linn, J. G., and N.P.Martin. 1999. Forage Quality Tests and Interpretations, http://extension.umn.edu/distribution/livestocksystems/ID26 37.html (Accessed June, 10, 2014)

Pinkerton,B.W.andCross, D.L., 1992. Forage quality. http://www.clemson.edu/ psapublishing/ Pages/AGRO/forage16.pdf (Accessed June, 15, 2014)

Serin, Y., A.Gokkus, M.Tan, A.Koc and B. Comakli. 1998. Determination of appropriate mixtures artificial grass and forage crops, Tr. J. of Agriculture and Forestry, 22, 13-20

Sheaffer, C.C., M.A. Peterson, M.Mccalin, J.J.Volene, J.H.Cherney, K.D.Johnson, Woodward, W.T., and Viands, D. R., 1995. Acid Detergent Fiber, Neutral Detergent Fiber Concentration and Relative Feed Value, North American Alfalfa İmprovement Conference, Minneapolis

Skerman, P.J., and F.Riveros. 1990. Tropical Grasses. FAO Plant Production and Protection Series 23, Roma. 832 p.

Spandl, E., and O.B.Hesterman. 1997. Forage Quality and Alfalfa Characteristics in Binary Mixtures of Alfalfa and Bromegrass or Timothy. Crop Science, 37 p:1581-1585.

Steel, R.G.D. and J.H.Torrie. 1960. Principles and Procedures of Statistics With Special Reference to the Biological Sciences. Mc Graw-Hill Book Co., Inc., London.

Tansi, V. 2009. Rhodes grass, Forage Grasses and Other Forage Plants from Other Families, (Avcioğlu, R., Hatipoğlu, R., Karadağ,Y (editors), Vol III. TÜGEM, Emre Basımevi, İzmir, (2009), P: 733-737.

Tessema, Z. and R.M.T.Baars. 2006. Chemical Composition Dry Matter Production and Yield Dynamics of Tropical Grasses Mixed With Perennial Forage Legumes, Tropical Grasslands Volume 40 p: $150-156$

Uzun, F. 2010. Changes in hay yield and quality of bulbous barley at different phonological stages. Turk J Agric For 34: $1-9$ 